\title{
Mezi občanským a soukromým právem. Systematické pojetí výuky na Katedře občanského práva Právnické fakulty Masarykovy univerzity
}

Between Civil and Private Law. Systemic Conception of Teaching at the Department of Civil Law, Faculty of Law, Masaryk University

\author{
Jan Hurdík $k^{*}$
}

\begin{abstract}
Abstrakt
Clánek nabizi shrnujici pobled, „zevnitr" na historii systémovébo pojetí a vaájemných systémových vazeb občanskébo a soukromébo právo a na jejich odraz ve strukture katedry občanskébo práva a v systémovém prìstupu ke výuce občanskébo práva od znovuobnoveni právnické fakulty v roce 1969 do soućasnosti, včetnè výbledu do budoucna.
\end{abstract}

Klíčová slova

Občanské právo; soukromé právo; systém soukromého práva; výuka občanského práva; obecné soukromé právo; zuláštni soukromá práva.

\begin{abstract}
The article offers to the reader the summarizing, inside "look at the history of structure and system of private/ civil law from the renewal of faculty of law (1969) till today and on the infuencing of structure of department for civil law and of teaching procedure at the department, including the prospect to the future.
\end{abstract}

Keywords

Civil Law; Private Law; System of Private Law; Teaching of Civil Law; General Private Law; Special Private Laws.

\section{Úvodem}

Jedna z největších autorit české civilistiky Viktor Knapp prohlásil před léty, že vrcholem kariéry vysokoškolského profesora by mělo být napsání učebnice svého oboru. Tento bonmot vyjadřuje poslání vysokoškolského vzdělávacího systému: přetavit poznatky vědy svého oboru do uceleného systému zprostředkování zvládnutí oboru novými generacemi odborníků. Pro právní odvětví to znamená vytvořit převodovou soustavu mezi vědou a praxí na jedné straně a pedagogickým procesem na straně druhé. Zvládnout

\footnotetext{
* Prof. JUDr. Jan Hurdík, DrSc., Katedra občanského práva, Právnická fakulta, Masarykova univerzita, Brno / Department of Civil Law, Faculty of Law, Masaryk University, Brno, Czech Republic / E-mail: Jan.Hurdik@law.muni.cz
} 
toto zadání se pokoušeli mnozí představitelé svého oboru, jen část z nich však je nejen úspěšně koncipovala, ale rovněž uceleně promítla do pedagogické praxe.

Katedra občanského práva Právnické fakulty Masarykovy univerzity a její představitelé a spolupracovníci po celou dobu svého působení v oboru usilovali dosáhnout tohoto cíle. Aby se stal skutečným vrcholem a naplněním jejich často dlouholeté pedagogické praxe, na to plnili své poslání v měnících se společenských podmínkách a výuka jejích předmětů byla podrobena několika zásadním a řadě dílčích změn jak vnějšího prostředí, tak vlastního předmětu svého pedagogického působení. ${ }^{1}$

Reagovat na tyto změny předpokládá vnímat, že občanské/soukromé právo mají své institucionální i hodnotové, ale koneckonců i strukturální a funkcionální základy, které patři k trvalým evropským hodnotám a zůstávají zakódovány jako kořeny jinak dialekticky se měnící jevové podoby odvětví.

K tomu prristoupila měnící se masa informací potřebných k poznání a zvládnutí oboru. Cíl výuky práva byl podroben v uplynulých 70 létech významným změnám. Informační exploze a ubikvita informací, včetně právních, vedla k opuštění hlavního cíle v sumě poznatků o právu a zaměření pozornosti na metodologii, umožňující selekci, výběr a systémové uspořádání informací pro řešení právnických profesních zadání.

$\mathrm{V}$ rámci výuky práva připadlo vždy zvláštní poslání občanskému právu, které vždy a ve všech společenských systémech utvářelo základ právní regulace jako celku. Zároveň občanské právo bylo a je za všech okolností v nejužším kontaktu s vnějším světem společenských vztahů, z něhož čerpá podněty pro svůj rozvoj a skrze nějž se promítají politické koncepty uspořádání společnosti do ostatních částí právního řádu. Studium občanského práva je tedy třeba absolvovat paralelně se studiem vnějšího prostředí, s nímž se občanské právo vzájemně sebeutvářejí. Současně to klade pozornost na studium jak vnitřních struktur a vazeb, tak na jeho vnější vazby na společenské prostředí, v němž se právo občanské vyvijí, a v ideálním př́padě se ve vzájemné synergii obohacují: první z nich jako realita, druhý jako modelový odraz reality v jeho ideální podobè.

Význam občanského práva na klíčové pozici v soustavě právnického vzdělávání akcentuje současně hlavní tendence ke změnám výuky občanského práva $\mathrm{v}$ přelomově se měnící společenské realitě.

Poznat jádro právního řádu - občanské právo - v jeho rozsahu a obsahu znamená poznávat je především jako komplexní fenomén, k jehož zvládnutí je nutné metodologicky ovládnout jeho podstatu, právní povahu a funkce. Především však je nutné sledovat cíle, které právo sleduje, a jim všechny předchozí nástroje poznání občanského práva podřídit. Cíle jsou institucionální a hodnotové; oddělovat je navzájem by mělo podobně tragický dopad, jako měla sekularizace práva v některých zemích Evropy, která odtrhla

1 Bliže viz VOJÁČEK, L., K. SCHELLE a J. TAUCHEN. Déjiny Právnické fakulty Masarykovy univerzity 1919-2019. 1. díl 1919-1989. 1. vyd. Brno: Masarykova univerzita, 2019, s. 355-383. 
od právního řádu sociální a mravní systém, na němž se vyvíjela po staletí Evropa, pohříchu právě v době, kdy byla naděje, že tyto systémy mohou vyústit v systém právních pravidel, budovaný na pevných mravních základech. Hodnoty, o něž by se měl opírat současný právní systém s jeho sociální funkcí, ztratily své zakotvení a potenciál koherentního rozvoje a tvoří i v občanském právu zdroj jeho nestability.

Za současných okolností se ukazuje, že požadavky na výchovu právníka, připraveného tyto výzvy uchopit a ve své profesi je naplnit, směřují ke schopnosti abstrahovat nespočetné variability společenských situací do modelů, jejichž zpracování je označováno jako symbolická analýza. ${ }^{2}$

Dokonalá znalost systému práva, zejména v jeho funkcionalitě a výstupech do společenského prostředí a jeho ovlivňování, je tudíž základem kvalifikace civilisty. Právníkům je směřována často klíčová role v rozhodujících politických i ekonomických procesech; $\mathrm{k}$ tomu, aby této roli dostáli, na ni musí být připraveni.

At' si to výslovně přiznáme, nebo nikoli, ${ }^{3}$ právo je jedním z nejvýznamnějších řídicích systémů společnosti, a to i vzhledem k ovlivňování vývoje společnosti do její budoucnosti. Právník by měl dosáhnout vzdělanostního profilu, zahrnujícího:

a) Způsobilost pochopit a ovládat právo jako systém abstraktních symbolů;

b) s tím se pojí způsobilost abstrakce, která je základem zjednodušení, utváření modelů a tím tvưrčího myšlení;

c) s tím se pojí dále schopnost systémového myšlení jako metoda rozvíjející abstrakci;

d) systémové myšlení musí, aby splnilo požadavky na současného a budoucího právníka, překračovat hranice oborů, být multisystémové; svět nelze pochopit izolovaně;

e) systémové myšlení vede k nalézání, resp. formování modelů sociální interakce jako jádra symbolické analýzy.

f) Nezbytná je způsobilost vidět za těmito abstrakcemi a symboly sociální realitu a tuto prostřednictvím adekvátních modelů řešit; v rámci výuky konfrontací a reálným životem práva a jako cesta propojující oba světy - abstrakci a realitu - (sociálně) právní experiment.

Právo je strategickým nástrojem fungování společnosti. Studovat je znamená vést studenty naznačenou cestou. Občanské právo je pak v rámci práva oborem, který svou imanentní povahou popsané způsobilosti akcentuje.

Měnící se právní rády nejsou v tomto procesu překážkou, na kterou by student, resp. právník neměl být připraven: v tomto prostředí se student vyvíjí, v dynamickém prostředí reálného života se formuje právník. Na překážku není měnící se právní rád pro tuto situaci je právník školen. Na překážku není ani nedostatek hluboce a široce pojatého univerzálního vzdělání právníka: konceptualizace a řešení problémů je otázka

2 REICH, R. B. Dílo národi. Přphrava na kapitalismus 21. století. Praha: Prostor, 2002, s. 258-267.

3 ELIÁŠ, K. a kol. Nový občanský zákoník s aktualizovanou diovodovou zprávou. Ostrava: Sagit, 2012, s. 37 , s. 42. 
obecných metodik, které se neváží na jedinou profesi. S tím se pojí požadavek, aby právo nesměřovalo $\mathrm{k}$ výchově individualistů, nýbrž komunikativních typů, způsobilých diskuse, potažmo profesionální včetně interdisciplinární konfrontace, odborníků zpo̊sobilých k týmové spolupráci.

\section{Vnímání soukromého a občanského práva a odraz ve výuce po obnovení Právnické fakulty Univerzity Jana Evangelisty Purkyně}

Vnitřní systematické uspořádání právního řádu nebylo v minulosti až do současné doby neochvějným pilířem a faktorem stabilizace právních řádů jako jednou pro vždy uspořádaného celku. ${ }^{4}$ To se projevilo v novodobých dějinách zejména v České republice, kde politické zásahy do právního řádu v období let 1948-1989 se významně projevily v pojetí systému práva a následně zasáhly i do vnitřní organizační struktury československých právnických fakult. Brněnská právnická fakulta byla historicky tomuto vlivu vystavena ještě výrazněji: Její obnovení v roce 1969 vytvořilo prostor pro volnější, tradiční organizační strukturou nezatížená experimentování s uspořádáním kateder. ${ }^{5}$

Shodou okolností spadalo obnovení brněnské právnické fakulty do období následujícího po jednom z největších experimentů v pojetí a systému dosavadního soukromého práva, který svou hloubkou a rozsahem neměl - s výjimkou tehdejší Německé demokratické republiky - srovnání ani s jinými právními řády tehdejš̌ího východního bloku. ${ }^{6}$

Tím způsobem došlo k synergickému efektu vytvoření prostoru pro vnitřní organizační katedrovou strukturu Právnické fakulty UJEP v Brně, v níž se mohl naplno projevit odraz konceptu právní regulace a vnitřního členění právního řádu tehdejší ČSSR. Jen zčásti se na tomto uspořádání odrazily výsledky vědeckého výzkumu v oblasti systému práva na brněnské fakultě (více viz dále).

Systém právního řádu byl doktrinálně řešen cestou odmítnutí systému soukromého a veřejného práva a jeho nahrazení systémem, jehož odvětví byla vymezena rolí určité skupiny společenských vztahů v procesu ekonomické reprodukce úhrnného společenského produktu. $^{7}$ Toto hledisko se stalo základním kritériem členění právního řádu v oblasti dřive zahrnuté pod soukromé právo, doplňujícím kritériem se stal předmět právní regulace. Takto vytvořená právní odvětví byla, každé samostatně, vymezena prostřednictvím pozitivně určeného okruhu společenských vztahů jím regulovaných. Občanské právo ztratilo význam obecného odvětví, subsidiárně použitelného pro odvětví ostatní

4 Srov. mj. HURDÍK, J. a M. SELUCKÁ. Hrozí smrt soukromého práva? Právník, Praha: AV ČR, Ústav státu a práva, 2019, roč. CLVIII, č. 1, s. 18-31.

5 Bliže viz VOJÁČEK, L., K. SCHELLE a J. TAUCHEN. Dẹjiny Právnické fakulty Masarykovy univerzity 1919-2019. 1. díl 1919-1989. 1. vyd. Brno: Masarykova univerzita, 2019, s. 355-383.

6 KOLEKTIV. Ceskoslovenské občanské právo, sv. I. Praha: Orbis, 1974, zejm. s. 10-20.

7 Bliže WLODYKA, S. Problem struktury prawa. Państwo i prawo, 1995, č. 4, s. 4 a násl.; srov. též KOLEKTIV. Občanské právo, sv. I. Praha: Orbis, 1974, zejm. s. 14-15. 
(se zmíněnou výjimkou rodinného práva) a stalo se odvětvím, regulujícím oblast konečné spotřeby úhrnného společenského produktu v oblasti vztahů majetkových a osobních (resp. osobnostních a osobně majetkových), přičemž alespoň jedním z účastníků těchto vztahů musela být osoba fyzická. ${ }^{8}$

Legislativa tento př́stup poměrně důsledně respektovala a přijala v reformních létech 1963-1965 soubor relativně vysoce autonomně koncipovaných úprav jednotlivých odvětví, řazených jinak do soukromého práva: vedle občanského zákoníku č. 40/1964 Sb. ${ }^{9}$ to byly zejména zákoník práce č. 65/1965 Sb., hospodářský zákoník č. 109/1964 Sb. Míra jejich autonomie byla vyjádřena i vzájemnou použitelností těchto předpisů: s výjimkou zákona o rodině č. 94/1993 Sb., které byl ve svém odkazujícím \104 napojen výslovným pravidlem speciality a subsidiarity na občanský zákoník, ostatní kodexy byly postaveny na odlišném hodnotovém souboru zásad a odlišném postavení jejich subjektů. Specifické místo měl občanský soudní řád č. 99/1963 Sb., jehož integrita s odvětvími „soukromého“ práva byla tehdy odůvodňována marxistickou tezí o „procesu jako formě života hmoty“. ${ }^{10}$ Zcela zvláštní postavení měly v té době kodexy a další předpisy, které měly umožnit průchodnost regulace odvětví občanského, obchodního, rodinného či pracovního práva v mezinárodním styku: pro tyto účely byl koncipován nejen (v nadnárodním srovnání standardní) zákon o mezinárodním právu soukromém a procesním č. 97/1963 Sb., nýbrž - jako svého druhu evropská rarita - i zákon č. 101/1963 Sb., zákoník mezinárodního obchodu, který pro oblast mezinárodního obchodního styku mimo země východního bloku, kde nová československá úprava byla inkompatibilní s evropskými standardy, vytvářel paralelní „,vnitrostátní“ úpravu pro oblast mezinárodního obchodního styku. ${ }^{11}$

Dominujícímu konceptu odpovídalo katedrové uspořádání fakulty: katedry byly uspořádány poměrně důsledně podle odvětvového hlediska: vedle katedry hospodářského práva, pracovního práva a sociálního zabezpečení, mezinárodního práva, kam bylo integrováno i mezinárodní právo soukromé, byla zrrízena katedra občanského práva, zajišt'ující výuku občanského práva hmotného, rodinného práva a občanského práva procesního.

Tento systémově strukturní prrístup byl zachován na Právnické fakultě UJEP až do roku 1990, a to přesto, že právě tato fakulta a její katedra občanského práva se staly v průběhu 70. a 80. let nositeli změn v pohledu na systém práva a jeho kritéria. Profesor Josef Macur

8 Srov. HURDÍK, J., J. FIALA a M. HRUŠÁKOVÁ. Úvod do soukromého práva. 3., nezměněné vyd. Brno: Masarykova univerzita, 2006, s. 43.

9 Předmětem jeho úpravy byly vztahy vznikající v oblasti přerozdělování a spotřeby společenských statků, jakož i vztahy spojené s ochranou osobnosti a vztahy poskytující ochranu výsledkům tvưrčí duševní činnosti. Srov. původní znění $\int 1$ OZ 1964, srov. též HURDÍK, J., J. FIALA a M. HRUŠÁKOVÁ. Úvod do soukromého práva. 3., nezměněné vyd. Brno: Masarykova univerzita, 2006, s. 45.

10 MACUR, J. Občanské právo procesní v systému práva. Brno: Universita J. E. Purkyně v Brně, 1975, s. 167 a násl.

11 Zákonodárce výslovně stanovil v \497 obč. zákoníku 1964, že vztahy vznikající v mezinárodním obchodním styku jsou vztahy občanskoprávními. 
jako vưdčí osobnost brněnské a československé civilistiky se stal nositelem mj. propracovaných př́stupů $\mathrm{k}$ systému práva a místa civilního práva a civilního procesu v jeho rámci. Jako široce založené vědecké osobnosti se mu metodicky podařilo přxeklenout tradiční př́kopy západní a „socialistické“ právní vědy a předložit koncept systému práva založený na souboru tezí: (a) Systém práva je utvářen specifickými funkčními vazbami mezi objektivními zájmy. (b) Jejím základem je pojetí funkcí práva jako integrace zájmů v právních vztazích. ${ }^{12}$ (c) Variabilita integrace zájmů je určena povahou a mírou společenské integrace. ${ }^{13}$ (d) Přitom je důležité, co je integrováno (zde je cesta k předmětu právní regulace jako kritériu systému práva) a jak je integrováno (tedy metoda právní regulace jako výraz podstatných vlastností předmětu právní regulace). ${ }^{14}$ Ačkoli Macur nemohl překonat tehdejší dominující systemizaci právních odvětví podle místa jimi regulovaných společenských vztahů ve společenské dělbě práce, jeho dílo bylo způsobilé akceptovat tehdy kategoricky odmítanou dichotomii soukromé - veřejné právo a navíc umožnilo dále rozvíjet systém práva na sekundární úrovni. ${ }^{15}$ Zajímavostí je, že Macur už tenkrát cituje řadu autorů, varujících před ( $z$ dnešního pohledu zcela aktuálními) tendencemi ohrožovat systém soukromého práva ,invazí veřejného práva do práva soukromého“, před „publicizací občanského a pracovního práva“ a připomíná mj. již tehdy letitou Weyrovu tezi o „pohlcení soukromého práva právem veřejným“. 16

Macurovo vědecké dílo, které po dvacet let profilovalo katedru občanského práva, do značné míry překonalo dobové politické a doktrinální sevření a vytvořilo předpoklady pro soudobé dotváření konceptu systému práva, který - pravda - nebyl přjijat československou legislativou 70. a 80. let 20. století a do zásadního uspořádání struktury výuky byl promítnut pouze zčásti. ${ }^{17}$ Jako vědeckému konceptu se mu však dostalo uznání vědeckou civilistickou frontou bezprostředně po jeho publikaci a jeho doktrinální myšlenky výrazně ovlivnily obsah přednášek občanského práva hmotného i občanského práva procesního na brněnské katedře již před rokem 1989. Jeho koncept, pěstovaný Macurovými pokračovateli, dodnes soupeří s tradičními modely systému práva, ${ }^{18}$ ačkoli si své místo v doktríně právní systematiky dokázal obhájit.

12 MACUR, J. Občanské právo procesni v systému práva. Brno: Universita J. E. Purkyně v Brně, 1975, s. 104.

13 Ibid., s. 105.

14 Ibid., s. 106, 109, 116.

15 Ibid., s. 126.

16 Ibid., s. 127 a citace č. 64, č. 65.

17 VOJÁČEK, L., K. SCHELLE a J. TAUCHEN. Déjiny Právnické fakulty Masarykovy univerzity 1919-2019. 1. díl 1919-1989. 1. vyd. Brno: Masarykova univerzita, 2019, s. 355-383, zejm. s. 376.

18 Ne vždy úspěšně: Srov. ELIÁŠ, K. a kol. Nový ob̌́anský zákoník s aktualizovanou diovodovou zprávou. Ostrava: Sagit, 2012, s. 55-62, kde uvedené odkazy a úvahy naznačují neuzavřenost otázky vymezení soukromého a veřejného práva. 


\section{Návrat k dominantní dichotomii soukromé - veřejné právo, jeho odraz ve výuce a její struktuře}

Mezník českého občanského práva představoval rok 1989, kdy české občanské právo vyhlásilo záměr opustit koncepci a systém socialistického práva a navrátit se k tradicím kontinentálního soukromého práva. Tato transformace však byla provedena jen zčásti. Místo rekodifikace občanského práva byla zvolena jeho - byt' rozsáhlá - novelizace a systém českého soukromého práva uvázl v odlišných kritériích členění systému soukromého práva a nebyl založen ani na dostatečně ustálených hodnotových základech, ani na doktrinálně, legislativně a prakticky koherentním systému vnitřního uspořádání. Zásadní zvrat bezprostředně nepřinesly ani politické požadavky změn v českém právu, spojené se vstupem České republiky do EU od 1. 5. 2004.

Stav soukromého práva a v jeho rámci práva občanského se ukázal do důsledků nereformovatelný bez koncepčního, systémového řešení. Politická rozhodnutí, směřující k rekodifikaci českého soukromého práva, po několika pokusech, které skončily bez výsledku, zahájila legislativní práce ojedinělého rozsahu, které postupně získaly širokou politickou podporu a byly ukončeny přijetím souboru kodexů soukromého práva a doplňující legislativou v roce 2012, většina z nich s účinností od 1. 1. 2014. Realizovanou reformou soukromého práva český právní řád vstoupil do jedoucího vlaku prrípravy a realizace projektů sjednocení evropského soukromého práva i reformy národních právních řádů. Tato situace akcentuje dynamicky pojaté metody studia a vývoje práva, jako metodu procesně genetickou.

Ačkoli se základní obrysy občanského práva po reformě v roce 2012 v současnosti zdánlivě ustálily, jde o jevovou stránku, pod jejíž hladinou víŕi spodní proudy probíhajícího vnitřního a zejména vnějšího vývoje. Jakékoli hodnocení či koncept studia, resp. výuky občanského práva má z tohoto pohledu relativní povahu. Teprve historie ukáže výsledky této dějinné zkoušky, založené na konfrontaci právního konstruktu s realitou, jejíž obrysy dnes nikdo nedohlédne.

Ve výuce občanského práva na Právnické fakultě MU byl od počátku 90. let 20. století prosazován systémový i obsahový koncept, odrážející ideový, resp. hodnotový návrat občanského práva mezi tradiční západoevropské právní rády, změny jeho systému i změny institucionální. Z iniciativy kateder soukromého práva byl od počátku 90. let prosazován proces vnitřní integrace právnického vzdělávání v podobě blokového studia s vlajkovou lodí v podobě relativně vysoce integrovaného bloku soukromoprávního a jeho pilotní disciplíny - Úvodu do soukromého práva, kdy blokové studium, ukončované blokovou zkouškou, se stalo páteří celého právnického magisterského vzdělávání. Tento organizační krok byl doprovázen zpracováním učebnice věnované společnému úvodnímu výkladu soukromého práva. ${ }^{19}$ Pohříchu, namísto pedagogického a odborného

19 HURDÍK, J., J. FIALA a M. HRUŠÁKOVÁ. Úvod do sonkromébo práva. Brno: Masarykova univerzita, 1. vyd. 1998, 2. vyd. 2002, 3. vyd. 2006. 
dobudování této výukové soustavy byl tento koncept postupně rozmělňován, až došlo k jeho úplnému opuštění, a to z důvodů překážek při jeho praktickém zabezpečení.

Paradoxně rozporné vlivy přineslo pro plnění ambicí právnického vzdělávání prosazení boloňského procesu s jeho vícestupňovostí právnického studia i tendence prostupnosti studijních programů právnického a neprávnického zaměření. Limity těchto programů se ukázaly nedostatečně způsobilé plnit náročné cíle výchovy právníka typu vysoce erudovaného symbolického analytika. ${ }^{20}$ Základem reálných předpokladů a ambicí prrípravy kvalifikovaných právníků zůstává tedy nadále „dlouhý“ magisterský program. ${ }^{21}$

Paralelně se ubírajícím procesem spolu s rozvojem „,národního“ soukromého práva je proces, označovaný jako „europeizace“ soukromého práva. ${ }^{22}$ Jeho působení zasáhlo plnou silou české soukromé právo až po vstupu do 21. století. Po období cca mezi léty 2000 a 2008/2009 se tato tendence k unifikaci evropského soukromého práva jevila jako přímočará a směřující neochvějně $\mathrm{k}$ cíli formulovanému Evropským parlamentem v podobě budoucího evropského občanského zákoníku. Koneckonců byla tato snaha korunována celým souborem soft law projektů sbližování evropského soukromého práva v jeho jednotlivých segmentech, at' již spadaly do společných evropských kompetencí či nikoli, jako Tort Law Principles (2005), Draft Common Frame of Reference (2009) či Acquis Principles ze stejné doby. Realizace těchto projektů do legislativní unijní podoby však začala narážet na překážky, které tento proces zbrzdily v jeho ambicích. Po světové finanční krizi z let 2008/2009 se unifikační trendy stávají stále více obětí různic a diverzifikace i dř́ve společně deklarovaných postojů a výhled europeizace se stává méně zřetelným než dříve.

Katedra občanského práva spolu se sesterskými soukromoprávními katedrami usiluje již od roku 2004 řešit otázku výuky Evropského soukromého práva (když základem soustředěného studia se stal výzkumný záměr právnické fakulty v létech 2005-2011, zaměřený na vývoj českého práva po vstupu do EU, na který navázal v létech 2016-2018 mezikatedrový fakultní projekt Evropské soukromé právo). V současnosti má k dispozici vlastní dvoudílnou monografii, která je koncipována jako relativně koherentní učební pomůcka. ${ }^{23}$ Předmět Evropské soukromé právo a jeho zařazení do výuky jsou stále předmětem úvah, které do jisté míry živí i nejistota vývoje evropské integrace a neustálenost kritérií vymezujících případnou pedagogickou disciplínu i jejích mezipředmětových vazeb (viz též úvahy v bodu 4).

20 Jedním z hmatatelných limitů se ukázaly studijní nároky potřebné pro zvládnutí základu studia práva občanského práva, byt' v rozsahu alespoň jeho obecné části.

21 Jak potvrdila i institucionální akreditace tohoto programu v roce 2018.

22 Za jeden z nejvýznamnějších impulsů je považováno usnesení Evropského parlamentu z 26. 5.1989 o sblížení soukromého práva členských států (J.o. ES C 205, s. 518), následované celou řadou dalších.

23 KOLEKTIV. Evropské soukromé právo v čase a prostoru. I. díl: Cást teoretická, metodologická a systémová. Brno: MU, 2017; KOLEKTIV. Evropské sonkromé právo v čase a prostoru. II. díl: Cúst deskriptivní, analytická a systémově analytická. Brno: MU, 2018. 


\section{Dovršení pozice soukromého práva po rekodifikaci a promítnutí do struktury a obsahu výuky. Stimuly a překážky.}

Zdálo by se, že všechny důvody hovoří pro komplexní systémovou integraci výuky soukromého práva. Vyvstává však otázka: Lze vstoupit do téže řeky? Překážky, které se staví do cesty sjednocení soukromého práva, tvoří především v předchozím období výrazně samostatněji vystupující odvětví, která dnes tendují do okruhu „zvláštních soukromých práv“" v širším smyslu. ${ }^{24}$ Vznikají tak soubory otázek:

a) Systémová setrvačnost rodinného práva ani po novelizacích obč. zákoníku a zákona o rodině z 90. let ani po rekodifikaci soukromého práva z roku 2012 nenarazila na zásadní systémové problémy při organizaci výuky. „Legendárni“ \ 104 dřrivějšího zákona o rodině položil základ systémového vztahu subsidiarity a speciality občanského a rodinného práva, který se uplatnil zásadně i poté, kdy se rodinné právo stalo legislativní součástí občanského zákoníku (část druhá) a byla do něj inkorporována i většina majetkových práv, vázaných na rodinně právní status. Výuka rodinného práva byla a je součástí výuky katedry občanského práva jako zvláštní předmět, který se svými systémovými vazbami a obsahem netají vysokým stupněm provázanosti s obecným občanským právem. Určité otazníky snad vyvolává systémová pozice rodinného práva jako zvláštního soukromého práva či jako součásti práva občanského. ${ }^{25}$

b) Obchodní právo si v oblasti vědecké i pedagogické podrželo - zrèetelně i díky vysokému stupni erudice jeho pedagogů - rozsáhlé pedagogické přesahy do občanského práva. Tuto pozici si udržuje dlouhodobě. Ačkoli vedení fakulty mělo opakovaně zájem situaci řešit, řšení vždy víceméně potvrdila funkčnost statu quo, vyznačujícího se řadou průniků a duplicitami v obsahu výuky katedry občanského a katedry obchodního práva. ${ }^{26}$

24 Zvláštní soukromá práva v širším smyslu zde označují ty relativně ucelené soubory vztahů, odlišené modifikovanou soukromoprávní metodou, která - na rozdíl např. od pracovního práva jako zvláštního soukromého práva par excellence - jsou alespoň zčásti integrována v textu občanského zákoníku (rodinné právo, obchodní právo, soukromoprávní ochrana spotřebitele) a ne zcela vyhovují konstrukci 〔 3029 obč. zákoníku 2012).

25 Srov Ibid.

26 Zde se zřejmě sluší, pro svou vypovídací (a pro další reformní úvahy historickou) hodnotu, připomenout z poslední doby: Společné stanovisko kateder občanského práva a obchodního práva k dělbě a koordinaci výuky občanského a obchodního práva na $\operatorname{PrF}$ MU z 5. 1. 2018, předložené vedoucími obou kateder jako podklady pro vedení fakulty a akademický senát PrF MU:

„Problém délby práce mezi obory (katedry) občanskébo a obchodního práva neni kvalitativnè nový. Vąhledem ke podstatně vétši dvojkolejnosti úpravy právnickéch osob i závazkủ byla drúve jen snažši identifikace okerubü, jïmiž se má ve výuce zabývat ta či ona katedra... Sjednoceni podstatné ćásti právni úpravy téchto oblasti do platnébo OZ č. 89/2012 Sb. pouze snižilo (ale neodstranilo) faktickou dvojkolejnost úpravy závazkủ i právnických osob.systémovè je obchodni právo považováno za „zvlástni soukromé právo“, vedle pracovního práva či rodinného práva, jim ̌̌ je vyčlenèn rovněž relativně samostatný výukový prostor... Postaveni obchodního práva vĩč právu občanskému odpovídá relativnè samostatné pedagogické zpracováni a podáni obchodního práva jako materie navazujici na společné základy, která se v cásti úpravy „specializuje" na obchodně práuni vataby (zejm. právo obchodnich korporaci a závazkové právo... I pred rekodifikaci soukromébo práva navazovala výuka ObchP na obecnèjsi ObčP; to predpokládalo zopakovat v ObchP základni východiska a rozvijet

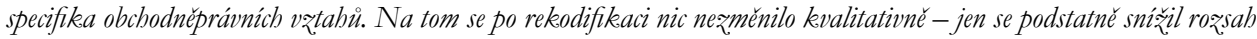
onèch specifik. Na to KObchP reagovala snižęením rozsabu výuky obecných otázeke a rozšírením speciálni výuky... hranice pedagogických disciplin neurčuje ostatně formálnè technické utváreni právníbo rádu (existence č neexistence kodexü nebo zulástnich ,oborových' zákonů)... Délba práce se usadila' a funguje prữně a zásadnè dobré. 
c) Systémová řešení výuky předmětů soukromého práva ovlivňuje zvlášt' výrazně subjektivní samostatnost a objektivní systémová odolnost pracovního práva. Jeho představitelé, kteří si přes snahy integrovat pracovní právo v jeho soukromoprávní části do nového civilního kodexu zachovali legislativní samostatnost pracovního práva v podobě zákoníku práce (2006), si uhájili i poměrně vysoký stupeň samostatné organizace výuky pracovního práva. Tato samostatnost je legislativně i v praxi respektována. Přesto jsou namístě úvahy o výrazně vyšším systémovém propojení pracovního práva s právem občanským, resp. o vyšším stupni využití obecné úpravy občanského zákoníku v prostoru zvláštního soukromého práva pracovního.

d) Návrat základní dichotomie práva soukromého a veřejného po roce 1989 nebylo možno odbýt pouhým deklarováním „návratu k evropskému standardu“. Jde o systémové otázky, které vyžadovaly jak vymezit genera, tj. společné rysy systémové úrovně soukromého práva, tak species, tj. ty systémové úrovně, které vytvářejí podružnou strukturu soukromého práva. Obě zadání vyžadovala určit kritéria uplatnitelná na obou těchto úrovních a na jejich základě dobudovat teoreticky argumentované a prakticky funkční systémové řešení.

Toto zadání řešil s úspěchem před desítiletími Josef Macur ${ }^{27}$ formulací kritérií metody a předmětu právní regulace.

Při vědeckém i pedagogickém uspořádání předmětu soukromého práva však vyvstaly některé systémové otázky, které provázejí soukromé právo již od klasického římského práva: jednou z nich se stalo pojetí věci, potažmo odlišení věcí hmotných a nehmotných a na tomto základě se odvíjející osud regulace společenských vztahů k nehmotným věcem, zejména pak jejich nejrozsáhlejší části, kterou tvoří právo duševního vlastnictví.

Velký problém $\mathrm{v}$ integraci práva $\mathrm{k}$ nehmotným statkům $\mathrm{v}$ dř́vějším právním řádu představovalo dilema mezi pojetím věci, které občanský zákoník z r. 1964 převzal do svého $\int 118 \mathrm{z}$ německého $\mathrm{BGB} \mathrm{v}$ užší podobě pouze hmotných předmětư ${ }^{28}$ a (ne)navazující mechanickou integrací práv k nehmotným statkům do civilního kodexu (『1), prričemž mezi uvedenými systémovými kroky nebyla vytvořena pevná systémová vazba (ani legislativní, avšak ani dostatečně propracovaná doktrinálnî).

Řešení právního režimu věcí v procesu rekodifikace stálo historicky před dilematem, postupovat bud’ na základě Gaiovy definice: „Omne autem ius, quo utimur, vel ad personas

$\cdots$

Náméty na réseni:

Navrbujeme., aby se prè jakýmkoliv zásahem do funkéního a ustálenébo rozdèleni a struktury výuky (tedy pred jinou než evolučni zmènou) občanskébo a obchodního práva provedla dỉkladná a nepredpojatá analýza současného stavu výnky, jeho

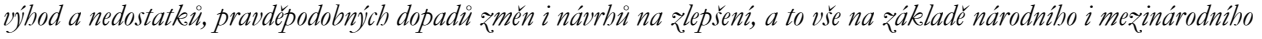
srovnání.. Prípadné závèry, pokud budou ve prospèch výraznèjš̌ch żmèn, budou zavádèt mladi perspektivni učitelé obou kateder - proto by se méli do analýzy zapojit prédevšim oni, ale ani żušenost, bistorické pamét' a (zdravý) konzervativizmus či skepticismus staršich kolegü by nemély být opomenuty. "

27 Srov. více v bodu 1 tohoto prríspěvku.

28 Viz dále citace č. 30. 
pertinet, vel ad res, vel ad actiones... “29, nebo na základě německé moderní školy, uznávající pod pojmem věc pouze hmotné předměty. ${ }^{30}$ První koncept vyústil v pojetí věci v rakouském ABGB (1811), francouzském Code civil a dalších kodexech, reprezentantem druhého je především německý BGB (1900). ${ }^{31}$ Český zákonodárce zvolil prvně zmíněný koncept jednotného pojetí věci v právním smyslu, čímž otevřel cestu systémové a komplexní integraci práva k nehmotným statkům obecně, speciálně pak práva duševního vlastnictví do systému soukromého práva. Současně český zákonodárce učinil významný integrační krok vstříc právu duševního vlastnictví, když vedle společné úpravy hmotných a nehmotných věcí v obecné části obč. zákoníku zakotvil do souboru smluvních typů rovněž typové smlouvy, jejichž předmětem jsou nehmotné věci, resp. práva duševního vlastnictví. ${ }^{32}$ Přesto však se právo duševního vlastnictví rozvíjí nadále $\mathrm{v}$ národním i nadnárodním měřítku jako relativně samostatná disciplína právní vědy, byt' po boku občanského práva.

Otázka ambivalentní systémové pozice práv k nehmotným statkům vưči soukromému právu se ukázala dlouhodobě odolná jak vưči doktrinálním řešením, tak odvozeně i vưči systematickému zařazení do výuky práva. Tomu nasvědčují nejen samostatně vyučované předměty práva duševního vlastnictví, ale i organizačně samostatné pedagogicko-vědecké útvary v rámci univerzitních pracovišt'. ${ }^{33}$

Sumarizace společných a specifických znaků občanského práva a práva duševního vlastnictví ukazuje na specifikum postavení práva $\mathrm{k}$ nehmotným věcem: obvykle uplatňovaná metoda právní regulace, spočívající v povaze uplatnění veřejné moci na daný okruh společenských vztahů, se u práv k nehmotným věcem neuplatní, resp. nemá zde kriteriální povahu. Naopak kritériem zde je zvláštní povaha nehmotných věcí, která se svými technikami chování a regulace vymyká standardům soukromoprávní regulace, dlouhodobě nastaveným na předměty v podobě věcí hmotných. Odtud pramení pochyby, zda oblast právní regulace, zaměřená na nehmotné věci, lze považovat za integrální součást občanského práva jako obecného práva soukromého, či za jedno ze zvláštních soukromých práv. ${ }^{34}$

29 Gai. 1,8.

30 Německý občanský zákoník ve své třetí knize nazvané věcné právo (Sachenrecht) definuje pojem věc

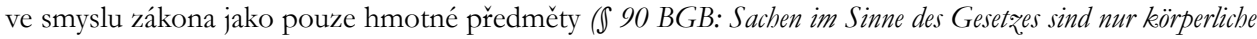
Gegenstände.).

31 Odlišné řešení předmětu soukromoprávní regulace přijal holandský občanský zákoník, který pod obecný pojem statky (goederen - čl. 3.1) řadí věci (pouze hmotné povahy) a dále všechna majetková práva (vermogensrechten - čl. 3.2) K okruhu majetkových práv řadí i výsledky intelektuální lidské činnosti jako intelektuální vlastnictví. Pohříchu toto řešení předmětu právní regulace nenašlo svůj odraz v českém obč. zák.

32 Typicky licence - $\int 2358$ n. či v rámci právní úpravy díla zvláštní režim díla s nehmotným výsledkem - \2631-2635.

33 Srov. Ústav práva duševního vlastnictví (Ústav práva autorského, práv průmyslových a práva soutěžního) v rámci pražské Univerzity Karlovy.

34 Srov. již zmiňovaný \3029 obč. zákoníku. 
Praxe ukazuje, že oblast práv k nehmotným věcem za daného stavu právní regulace obecného práva soukromého vykazuje taková specifika, která vyžadují zvláštní režim v segmentu, který si vyžadují specifika nehmotných věcí, jejich právní identifikace, jejich právní uchopení, odlišnosti dispozice s nimi aj. Ačkoli se obecně vzato právní režim věcí hmotné a nehmotné povahy postupně v dlouhodobé perspektivě sbližuje, tyto odlišnosti zatím trvají a vyžadují i odlišné pedagogické uchopení výuky práva k nehmotným věcem, potažmo práv duševního vlastnictví.

\section{e) Postavení Evropského soukromého práva a dopady na organizaci výuky}

Evropské soukromé právo patři $\mathrm{k}$ jedněm $\mathrm{z}$ nejcitlivějších bodů úvah o reformě výuky soukromého práva jako celku. Jeho materie souvisí a prolíná se na jedné straně s pedagogickou disciplínou Evropské právo, na druhé straně s „národními“ soukromými právy. V tomto prostoru je ESP do jisté míry sevřeno a hledá prostor pro svou existenci, především sebedefinici. Tato zadání jsou plněna týmy předních akademiků, kteří vytvořili základ konceptu Evropského soukromého práva jako pedagogické disciplíny. ${ }^{35} \mathrm{Na}$ evropské úrovni jsou oporou pro konstituování pedagogické disciplíny jak „existing European private law", tak soft law projekty smluvního (spotřebitelského), deliktního a dalších segmentů soukromého práva. Relevantní konstituování Evropského soukromého práva jako pedagogické disciplíny si ještě vyžádá širší a hlubší diskusi o začlenění do systému výuky soukromého práva.

f) Další faktory ovlivňující systémové uspořádání soukromého práva (a jeho výuky)

Jako dílčí, možná i podružná systémová otázka se v právních řádech členských států EU vynořilo a bylo řešeno systémové místo jednotlivých dílčích oblastí tvořícího se Evropského soukromého práva. Šlo především o ty segmenty, které se počaly utvářet s předstihem před ostatními i před celkem (který ostatně byl formován proti liteře primárního práva EU). V evropských, ale i národních podmínkách tuto úlohu vlajkové lodi sehrálo právo ochrany spotřebitele. Vedle řady dalších otázek, jednou z „mandatorně“ “̌ rešených je legislativní systémové zařazení soukromoprávní ochrany spotřebitele. Z důvodů teoreticky doložených i ryze pragmatických je zásadně voleno bud' zařazení spotřebitelského práva do rámce kodifikace občanského práva, nebo je tato oblast právní regulace vyčleněna do samostatných právní předpisů, byt' mohou mít relativně jednotnou podobu spotřebitelského kodexu. Český zákonodárce zvolil (asi aby neurazil) oba př́stupy: definici spotřebitele upravil v obecné části obč. zákoníku, základní právní úpravu zařadil do části čtvrté obč. zákoníku, část úpravy reguluje ve speciálních předpisech. Tím (žrejmě nechtěně) zkomplikoval úlohu všem, kteři se zabývají systémovým začleněním této oblasti, mj. hledání odpovědi na otázky: (a) Jde vưbec o jakoukoli systémovou část nějakého vyššího celku? (b) Je tímto vyšším celkem Evropské soukromé právo nebo jsou jím národní

35 Srov. TICHÝ, L., R. ARNOLD, J. ZEMÁNEK a T. DUMBROVSKÝ. Evropské právo. 4. vyd. Praha: C. H. Beck, 2011; JANČO, M., M. JURČOVÁ, M. NOVOTNÁ a kol. Európske súkromné právo. Bratislava: EUROIURIS, 2012, 542 s.; či z brněnského prostředí spoluřešitelé projektu Evropské soukromé právo v čase a prostoru 2016-2018 s jejich dvoudílnou stejnojmennou publikací (viz výše). 
závazková práva ze smluv, nebo jde o systémové propojení obou vyšších celků? (c) V intencích českého soukromého práva, je spotřebitelské právo zvláštním soukromým právem ve smyslu \3029 obč. zák.?

Z uvedených úvah se odvíjejí cesty, do jaké míry, resp. jak systematicky zakomponovat spotřebitelské (soukromé) právo do rámce pedagogického procesu. Ačkoli se část akademiků katedry občanského práva spotřebitelským právem speciálně zabývá a má v této oblasti evropské zkušenosti, zdá se, že hloubka poznání problematiky samotné neusnadňuje její systematické uchopení v pedagogickém procesu; spíše se zdá, že někdy je tomu opačně.

\section{Dopady na výuku - shrnutí stavu a výhledů}

Vyhlídky pedagogického uspořádání výuky občanského práva nebyly po delší dobu prioritou. Podobně jako impulsům vývoje systému soukromého práva i v pedagogické oblasti dominuje pragmatismus a do značné míry i kvantifikační limity zátěže studentů a tomu odpovídající metoda dílčích změn. Určitou šanci nicméně lze spatřovat v záměru vedení fakulty využít prostoru, vytvořeného novým systémem akreditací a řízení kvality, do kterého vstoupila MU v minulých létech. V rozhodnutí o institucionální akreditaci, kterou fakultě udělil Národní akreditační úrad, zároveň stanovil kontrolu po třech létech, $\mathrm{v}$ jejichž průběhu by fakulta měla realizovat potřebné změny klíčového magisterského programu Právo ve smyslu určujících aktuálních směrů vývoje realizace programů.

$\mathrm{V}$ těchto intencích se katedra občanského práva znovu vrací k myšlence aktualizace struktury výuky, kterou realizuje. Jako výchozí krok chce posílit roli obecné části soukromého práva návratem $\mathrm{k}$ formování samostatné části výuky $\mathrm{v}$ podobě předmětu Úvod do soukromého práva. Jeho návrh již byl zpracován v podobě blokové výuky. Jak uvádí návrh katedry k vedení fakulty, ,,v souvislosti s rekodifikaci došlo na poli soukromého práva k vyšš́ integraci a provázanosti v této oblasti práva, vyjádrené zejména novou pozicí OZ jako obecnébo kodexu soukromého práva. Cílem prèdmètu je uvést studenty do problematiky soukromého práva, vysvětlit je základni pojmy, koncepci, strukturu a instituty soukromébo práva. Předmét zprostredkuje studentiom ve strukturálně a systémovè ucelené podobè qákladni míru ,predporozumèni" pro dalši studium v navazujicich predmètech Občanské právo, Rodinné právo, Obchodni právo, Pracovní právo atd. a vytvárú prostor vénovat se v tèchto predmètech jejich vlastním tématuim vice do hloubkey. "Návrh je vybaven nově zpracovanou učební pomůckou. ${ }^{36}$ Současně se jako výraz kontinuity opuštěné fakultní a trvající katedrové koncepce komplexního pojetí soukromého práva vrací, jako k doporučené literatuře, k učebnici soukromého práva z doby blokové výuky. ${ }^{37}$ Vývoj konceptu výuky katedry občanského práva však nesměřuje jednosměrně pouze k vyšší systémové, obsahové a organizační koherenci. Důkazem snahy o systematickou

36 RONOVSKÁ, K., E. DOBROVOLNÁ a P. LAVICKÝ. Úvod do soukromého práva. Obecná část. Česká společnost pro civilní právo procesní, 2017.

37 HURDÍK, J., J. FIALA a M. HRUŠÁKOVÁ. Úvod do soukromébo práva. 2. vyd. Brno: MU, 2006. 
důslednost doktrinální jako východisko výuky je oddělení organizace výuky civilního procesu a soukromého práva hmotného jako výraz názoru na řešení dlouhodobě přetrvávající otázky samostatnosti a provázanosti civilního práva hmotného a procesního. Proces oddělení civilního procesu, započatý vytvořením oddělení civilního procesu ke dni 3. 10. 2017 jako součásti katedry občanského práva a dovršený vznikem katedry civilního práva procesního jejím oddělením od katedry občanského práva k 1. 1. 2019, signalizoval většinový př́klon katedry a fakulty k (jak ambiciózně konstatují tvůrci projektu) ,současným a jednoznačně uznávaným názorìm na postaveni civilního práva procesního, kteréna rozdúl od stavu v polovinè devatenáctého století - nelze považovat za soucást soukromého práva (či občanskébo práva ,hmotnébo \%. Jde o samostatné právni odvětví a o samostatný védecký obor, který má svioj predmèt, metody a hodnoty, jakož i své vlastni a mimorádnè bohaté teoretické zázemi. Rozdil obou oblasti je dán již tim, že občanské právo bmotné je základni disciplinou soukromébo práva, zatímco civilni právo procesni má verejnoprávni charakter. Proto predstava, ̌̌e existuje obor občanské právo', k.terý má část, hmotnou' a,procesni", je chimérou neodpovidajici současnému právnímu rádu ani dosaženému stavu védeckého poznáni. Tato okolnost se prakticky promitá i v pedagogickém procesu. Témata, otázky č problémy, s nimiž se musi vyporádat občanské právo hmotné či rodinné právo nebo právo duševního vlastnictvi - napr. pokud jde o rozsah a obsah výuky, zpuisob zkoušení, personální zajištèni výuky a zkoušek, potřeba zajištèni studijnich materiálù atd. -, se nijak netýkaji těch, jimžr. celi civilni právo procesní. "38

Je pravdou, že vznik katedry civilního procesu není prrijímán bez disentních postojů; tento krok však představuje mj. i signál, že po létech systematického budování toto odvětví dospělo vědecky, pedagogicky i personálně ke své maturitě.

Otázka stavu formování Evropského soukromého práva již byla řešena v předchozích bodech. Ve výhledu se v současnosti rýsují dvě základní cesty promítnutí evropského soukromého práva do výuky: (a) promítnutí jednotlivých segmentů evropského soukromého práva do výuky oblastí národního práva, $\mathrm{k}$ nimž předmětově, resp. metodou náležejí, resp. (b) zařazení do výuky magisterského studia práva předmětu Evropské soukromé právo. Posledně uvedený ambicióznější krok by bylo snadnější realizovat cestou povinně volitelného předmětu; zavedení nového povinného předmětu ESP by muselo mít vytvořený disponibilní prostor daný kvantifikujícími limity (zejm. počtem ECTS) a mohlo by být součástí šířeji koncipované reformy. Vždy je třeba počítat se dvěma silnými limitujícími faktory: časem a prostorem. V jejich rámci je jednodušší se vypořádat s tím, že evropské soukromé právo se postupně a obtížně vyvijjí od specifických k obecným řešením. ${ }^{39}$ Současně však do hry vstoupil faktor nejistot $\mathrm{v}$ budoucím

38 Citováno z dokumentu Organizačni a personálni zajištěni nově vaniklé katedry civilního procesu, předloženého katedrou občanského práva jako podklad pro jednání vedení fakulty v listopadu 2018. Ze soukromého archivu autora.

39 Srov. COLLINS, H. The European Civil Code. The Way Forvard. Cambridge University Press, 2008, s. 61-62. 
vývoji EU a jeho právního řádu. Učit evropské soukromé právo, ale i učit jen jeho zdánlivě pevný základ - spotřebitelské právo, tedy znamená „být vždy ve střehu“.

\section{Závěrem}

Nedůslednosti v organizaci výuky soukromého práva přetrvávají a obtížně se odstraňují metodou postupných kroků v mezích nastavených fakultních limitů - často kvantifikující povahy - vyšší úrovně.

Je obtížné si představit v dohledné perspektivě komplexní restrukturalizaci výuky soukromého práva jako celku, tím spíše, pokud máme držet krok s vývojem společnosti a práva a respektovat rysy vývoje, mezi něž náleží setrvačnost (odložená reakce) všech procesů, na jejichž konci je systematicky propracovaný a aktuální studijní program, resp. plán: setrvačnost začíná vnímáním společenských změn, pokračuje jejich odrazem $\mathrm{v}$ politických konceptech a následně v právní regulaci a ústí do konceptualizace a realizace změn ve výuce.

Uchopit soukromé právo aktuálně jako pedagogickou disciplínu tedy znamená věnovat se rysům, odrážejícím obor v systémovém a současně dynamickém kontextu a tvorbě tomu odpovídající metodologie, v intencích požadavků na povahu práce se soukromým právem jako symbolickou analýzu (viz v úvodu tohoto př́ispěvku).

Abychom se však vrátili ke vzpomínce z úvodu této statě: Jeden ze signálů, že katedra občanského práva na své cestě za poznáním a pedagogickým ovládnutím občanského práva dospěla ke zřetelné metě své vlastní pedagogické zpo̊sobilosti, bude - věřme spojen s okamžikem, kdy na Právnické fakultě MU bude zpracována ucelená učebnice systému (!) soukromého práva. 